\title{
PENGARUH APLIKASI PPA KADER TERHADAP PENGETAHUAN KADER TENTANG DETEKSI DINI STUNTING
}

\author{
Fika Kristi Febrina ${ }^{1}$, Novita Rina Antarsih ${ }^{2 凶}$ \\ ${ }^{1}$ Program Pendidikan Profesi Bidan Program Sarjana Terapan Poltekkes Kemenkes Jakarta III \\ ${ }^{2}$ Jurusan Kebidanan Poltekkes Kemenkes Jakarta III
}

\section{ARTICLE INFO \\ Article history}

Submitted : 2021-10-12

Revised : 2021-10-23

Accepted : 2021-11-25

\section{Keywords:}

Knowledge

Application

Stunting

$\triangle$ Corresponding Author:

\begin{abstract}
Stunting is a growth disorder due to a lack of nutritional intake for a long time. Data from the World Health Organization (WHO), the prevalence of stunting in Indonesia is the third highest in Southeast Asia. The PPA Kader application is one solution in helping to overcome the stunting problem because cadres can get information on nutritional status assessments so fast and can detect stunting early. PPA Kader application for monitoring the growth is an android-based application based on the $\mathrm{Z}$ Score value $(\mathrm{BB} / \mathrm{U}, \mathrm{TB} / \mathrm{U}, \mathrm{BMI} / \mathrm{U}$, and $\mathrm{BB} / \mathrm{TB})$, an imaginative and provocative medium for health education. To find out the effect of the PPA Kader application on the knowledge of village health workers about early stunting detection. This research was using pre-experimental research in one group pre-test post-test design. The research sample is 35 respondents taken from the village health worker population at the Integrated Services Post (Posyandu) in the area of the Public Health Center (Puskesmas) in Balik Bukit District with purposive sampling technique. This research was conducted from March to April. The intervention in this study was carried out using the PPA Kader application in which there was an educational explanation video about stunting. The data in this study were obtained through questionnaires that have been prepared for the pre-test and post-test to find out the knowledge of village health workers about early detection of stunting. Statistical test knowledge in this study is using Wilcoxon test. PPA Kader application can increase knowledge $(\mathrm{p}=0.000)$ of village health workers about early detection of stunting. The PPA Kader application affects the knowledge level of village health workers in the target area of the Balik Bukit District Health Center.

Stunting merupakan gangguan pertumbuhan karena kurangnya asupan gizi dalam waktu lama. Berdasarkan data dari World Health Organization (WHO), prevalensi stunting di Indonesia masuk ke dalam negara tiga tertinggi di Asia Tenggara. Aplikasi PPA Kader merupakan salah satu solusi dalam membantu mengatasi masalah stunting karena membantu kader mendapatkan informasi penilaian status gizi dalam waktu y ang cepat dapat mendeteksi stunting lebih awal. Aplikasi PPA Kader merupakan aplikasi berbasis android untuk pemantauan pertumbuhan balita berdasarkan nilai Z-Score (BB/U, TB/U, $\mathrm{IMT} / \mathrm{U}$, dan BB/TB) serta sebagai media pendidikan kesehatan yang bersifat imajinatif dan provokatif. Tujuan Penelitian adalah untuk mengetahui pengaruh aplikasi PPA Kader terhadap pengetahuan kader tentang deteksi dini stunting. Penelitian ini menggunakan metode penelitian pre-experimental dalam one group pre-test and posttest design. Sampel penelitian sebanyak 35 responden diambil dari populasi kader di Pos Pelayanan Terpadu (Posyandu) wilayah binaan Pusat Kesehatan Masyarakat (Puskesmas) Kecamatan Balik Bukit dengan teknik purposive sampling. Waktu penelitian ini dilakukan selama Bulan Maret sampai dengan April. Intervensi pada penelitian ini dilakukan dengan menggunakan aplikasi PPA Kader yang di dalamnya terdapat video penjelasan edukasi tentang stunting. Data pada penelitian ini diperoleh melalui pengisian kuesioner yang sudah disiapkan pada saat pre-test dan post-test untuk mengetahui pengetahuan kader tentang deteksi dini stunting. Uji statistik pengetahuan menggunakan uji Wilcoxon. Aplikasi PPA Kader dapat meningkatkan pengetahuan $(p=0.000)$ kader posyandu tentang deteksi dini stunting. Aplikasi PPA Kader berpengaruh terhadap tingkat pengetahuan kader Posyandu di wilayah binaan Puskesmas Kecamatan Balik Bukit.
\end{abstract}

Novita Rina Antarsih

Jurusan Kebidanan Poltekkes Kemenkes Jakarta III

Telp. 0817791115

Email: novitanuradi@gmail.com 


\section{PENDAHULUAN}

Stunting (pendek) adalah gangguan pertumbuhan linier yang disebabkan oleh kekurangan gizi dalam jangka waktu yang lama, yang dinyatakan dengan nilai Z-score tinggi badan berdasarkan umur kurang dari -2 SD. Anak yang mengalami stunting terlihat lebih pendek dibandingkan dengan anak seusianya (Al, 2015). Selain gangguan pertumbuhan, keadaan stunting pada anak juga memberikan dampak pada perkembangannya dalam jangka pendek maupun dampak jangka panjang (Utario and Sutriyanti, 2020).

Hasil penelitian yang dilakukan oleh Adilla et al tahun 2019 ada hubungan penting antara keterlambatan perkembangan dan IQ, yang merupakan tanda perkembangan otak. Dalam penelitian tersebut, dibandingkan dengan anak non stunting, anak dengan stunting memiliki skor IQ yang lebih rendah (Yadika, Berawi and Nasution, 2019). Penelitian lain yang dilakukan oleh Sri et al tahun 2018 pada balita usia 3 - 5 tahun di Posyandu Kricak Yogyakarta, hasil penelitian menyimpulkan bahwa ada hubungan antara kejadian stunting dengan perkembangan balita (Maharani, Wulandari and Melina, 2018).

Kejadian balita stunting merupakan merupakan masalah gizi yang sering dijumpai di negara berkembang khususnya Indonesia. Berdasarkan data dari World Health Organization (WHO), prevalensi stunting di Indonesia adalah yang tertinggi ketiga di Asia Tenggara. Rata-rata prevalensi balita stunting di Indonesia tahun 2005 - 2017 adalah 36,4\%. Berdasarkan Riskesdas 2018, Provinsi Lampung merupakan provinsi tertinggi ke-15 di Indonesia dengan prevalensi stunting yang mencapai $31,6 \%$ dengan angka kejadian tertinggi pertama di Way Kanan $(36,07 \%)$ dan angka kejadian tertinggi kedua di Lampung Barat (32,96\%). Hal ini menunjukkan bahwa angka kejadian stunting masih belum mencapai target WHO yaitu di bawah 20\% (Pusat Data dan Informasi Kemenkes RI, 2018) (Arthatiani, F. Y., \& Zulham, 2019) (Kementerian Kesehatan RI, 2018).

Masalah stunting disebabkan oleh beberapa faktor yaitu faktor langsung, faktor tidak langsung, dan akar masalah. Kondisi stunting ini berawal dari kurangnya asupan nutrisi yang dikonsumsi (Sulistianingsih and Yanti, 2016). Selain dari faktor-faktor penyebab tersebut, kejadian stunting juga bisa disebabkan karena kesalahan deteksi dini dalam menentukan status gizi pada tingkat dasar atau sejak awal oleh kader. Kesalahan deteksi dini ini dapat menghambat intervensi apabila anak mengalami gangguan tumbuh kembang (Azizah and Wardhani, 2020).

Kader merupakan masyarakat yang secara sukarela bersedia untuk menjadi pelaksana utama dalam Posyandu. Keberlangsungan kegiatan dalam Posyandu bergantung pada partisipasi aktif dari kader (Rahayu, 2017). Namun, pada saat melakukan kegiatan di Posyandu, kader hanya mengukur tinggi badan dan berat badan pada balita lalu mencatat ke buku kunjungan atau Kartu Menuju Sehat (KMS) tanpa melakukan interpretasi hasil pengukuran. Hal ini menunjukkan bahwa pengetahuan kader tentang pentingnya interpretasi data hasil pengukuran sebagai salah satu upaya dalam deteksi dini stunting masih kurang (Adistie, Lumbantobing and Maryam, 2018). Berdasarkan penelitian yang dilakukan oleh Heni, Zahroh, dan Aditya tahun 2020, hasil yang didapatkan adalah 40,6 $\%$ responden kader pada kelompok eksperimen yang memiliki pengetahuan kurang baik juga memiliki sikap yang kurang mendukung $(43,8 \%)$, self afficancy yang rendah $(46,9 \%)$, dan kemampuan praktik yang kurang baik $(40,6 \%)$ dalam deteksi pencegahan stunting (Purnamasari et al., 2020).

Peneliti sebelumnya melaporkan bahwa penggunaan aplikasi dalam smartphone merupakan software yang dapat digunakan dalam membantu kader untuk mendeteksi stunting (Handayani, Tarawan and Nurihsan, 2019). Kelebihan aplikasi stunting yang peneliti kembangkan adalah waktu untuk memahami dan menjalankan aplikasi sangat cepat dan mudah. Bentuk aplikasi ini secara online melalui link yang langsung dapat dilakukan instalasi pada android, adanya video tentang tugas, peran, dan fungsi kader posyandu; video tentang stunting, cara pengukuran Panjang Badan (PB) secara berbaring dan posisi berdiri; adanya hitung cepat pertumbuhan anak berdasarkan nilai Z-Score menggunakan 3 indikator pertumbuhan $(\mathrm{BB} / \mathrm{U}, \mathrm{TB} / \mathrm{U}$, dan $\mathrm{BB} / \mathrm{TB}$ ) yang diploting ke grafik (berdasarkan peraturan mentri kesehatan no 2 tahun 2020 tentang standar antropometri anak), adanya kumpulan daftar anak yang dimasukkan ke menu hitung cepat serta terdapat fitur download sertifikat penilaian pertumbuhan anak. 
Kabupaten Lampung Barat merupakan kabupaten dengan angka kejadian stunting tertinggi kedua di Provinsi lampung. Salah satu Puskesmas di Kabupaten Lampung Barat adalah Puskesmas Liwa Kecamatan Balik Bukit. Berdasarkan data dari bidan koordinator Puskesmas Liwa Kecamatan Balik Bukit, Posyandu di wilayah Puskesmas Kecamatan Balik Bukit ini berjumlah 27 Posyandu dengan jumlah kader rata-rata tiap Posyandu 4 sampai 7 orang.

Oleh karena itu, peneliti tertarik untuk melakukan penelitian tentang "Pengaruh Aplikasi Pemantauan Pertumbuhan Anak (PPA) Kader terhadap Pengetahuan Kader tentang DeteksiDini Stunting di Puskesmas Kecamatan Balik Bukit Tahun 2021”.

\section{METODE PENELITIAN Jenis Penelitian}

Penelitian ini merupakan penelitian kuantitatif dengan menggunakan desain Quasi Eksperimen dalam one group pre test post test design yaitu penelitian yang dilakukan dengan mengobservasi sebanyak 2 kali pada saat sebelum dan sesudah intervensi. Pada hari pertama, pertemuan dengan responden yang sesuai dengan kriteria inklusi di Posyandu.

Selanjutnya, responden akan dijelaskan tentang tujuan, manfaat, dan persetujuan penelitian untuk menghindari responden yang dropout saat penelitian berlangsung. Setelah penjelasan mengenai penelitian dilakukan, selanjutnya selama 35 menit responden melakukan pre-test dengan menggunakan kuesioner penelitian yang berisi 18 pertanyaan benar salah. Setelah itu, pemberian edukasi dan cara penggunaan aplikasi deteksi dini stunting dilakukan. Pada hari ketiga, pertemuan kembali dengan responden untuk melakukan posttest selama 35 menit dengan menggunakan kuesioner yang sama dengan saat pretest dilakukan.

\section{Lokasi dan Waktu Penelitian}

Penelitian ini berlokasi di Posyandu wilayah binaan Puskesmas Kecamatan Balik Bukit. Penelitian dilaksanakan pada bulan Maret April 2021

\section{Populasi dan Sampel}

Populasi penelitian ini adalah seluruh kader Posyandu wilayah Binaan Puskesmas Kecamatan Balik Bukit. Pengambilan sampel menggunakan teknik purposive sampling yaitu pengambilan sampel berdasarkan kriteria inklusi dan eksklusi. Berdasarkan penghitungan menggunakan rumus Lemeshow, besar sampel yang didapatkan adalah 35 orang.

\section{Pengumpulan Data}

Alat pengumpulan data yang digunakan pada penelitian ini adalah kuesioner dan tes hasil belajar (pre-test dan post-test) yang mengkaji pengetahuan kader Posyandu tentang deteksi dini stunting. Pre-test dilakukan pada hari pertama sebelum pemberian intervensi dengan menggunakan aplikasi PPA Kader. Kemudian, dilanjutkan dengan pemberian edukasi tentang penggunaan aplikasi PPA Kader. Pada hari ketiga, dilakukan post-test setelah pemberian intervensi menggunakan aplikasi PPA Kader.

Kelebihan aplikasi stunting PPA Kader yang peneliti kembangkan ini adalah waktu untuk memahami dan menjalankan aplikasi sangat cepat dan mudah. Aplikasi ini merupakan aplikasi berbasis android yang dapat di instalasi secara online melalui link.

\section{Pengolahan dan Analisis Data}

Penelitian ini telah melalui proses kaji etik Poltekkes Kemenkes Bandung dan mendapatkan Surat Keterangan Layak Etik dengan nomor 12/KEPK/EC/II/2021. Analisis yang digunakan dalam penelitian ini adalah analisis univariat untuk mengetahui distribusi frekuensi atau skor rata-rata pengetahuan kader sebelum dan sesudah diberikan intervensi, serta analisis bivariat menggunakan uji Wilcoxon karena data yang dapatkan berdasarkan uji normalitas menggunakan Saphiro-Wilk data pre-test dan pos-test berdistribusi tidak normal dengan nilai signifikansi 0,001 dan 0,002 $(<0,05)$.

\section{HASIL PENELITIAN Analisis Univariat}

Analisis univariat digunakan untuk menyajikan gambaran pada masing-masing variabel dalam penelitian di mana hasilnya diuraikan dalam tabel. Berdasarkan tabel 1 terdapat perbedaan skor median sebelum dan sesudah intervensi menggunakan media aplikasi PPAK dari 12 menjadi 15. Hal ini menunjukkan bahwa terdapat peningkatan pengetahuan Kader Posyandu sebelum dan sesudah diberikan 
intervensi pendidikan kesehatan dengan Aplikasi PPAK.

Nilai tengah skor pengetahuan kader Posyandu tentang deteksi dini stunting sebelum diberikan intervensi adalah 12 dengan standar deviasi 2,395 serta nilai minimal 5 dan nilai maksimal 16, sedangkan nilai tengah skor pengetahuan kader posyandu tentang deteksi dini stunting setelah diberikan intervensi dengan aplikasi PPAK adalah 15 dengan standar deviasi 2,313 serta nilai minimal 11 dan nilai maksimal 18.

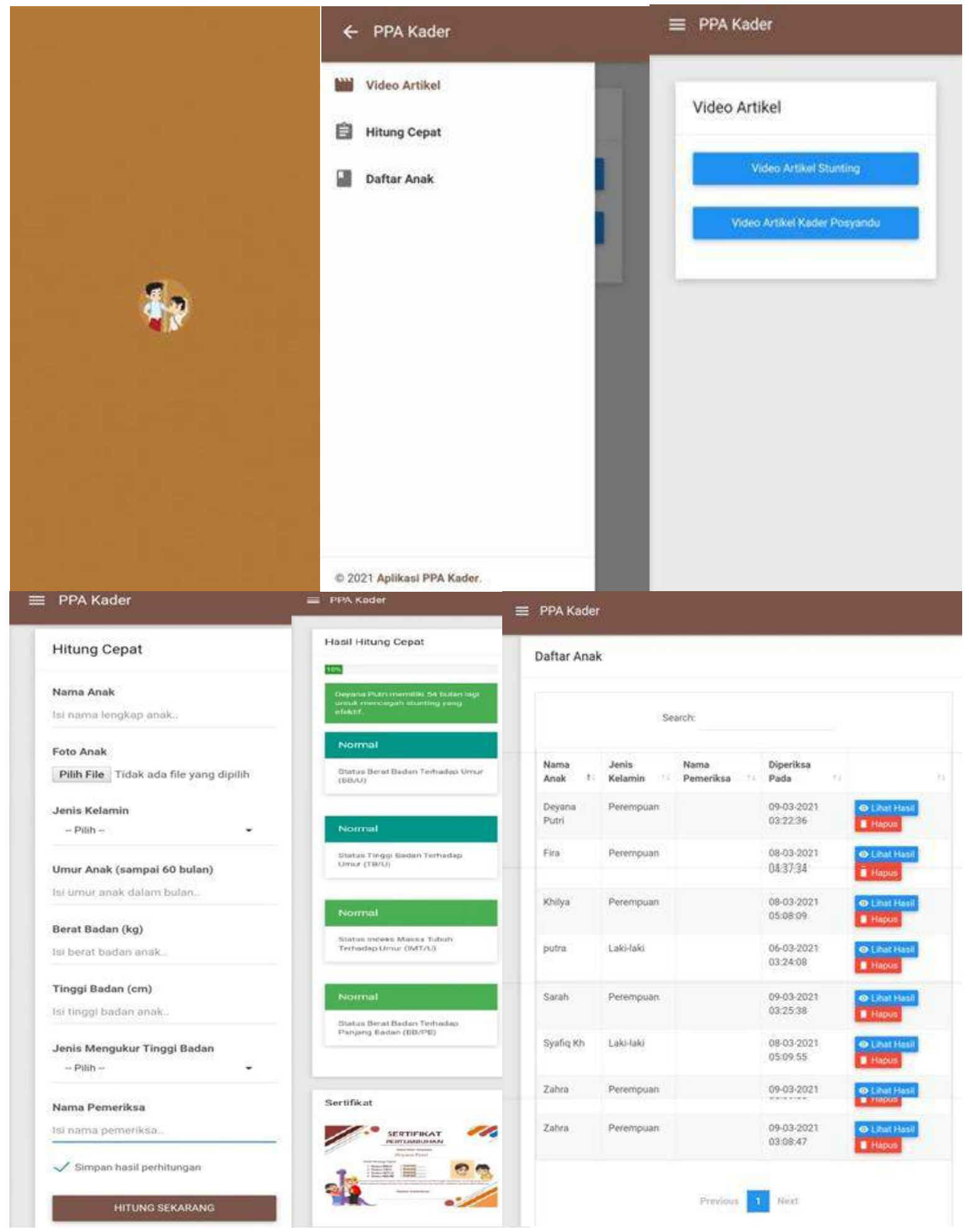

Gambar 1. Gambaran Aplikasi PPAK 
Tabel 1. Distribusi Frekuensi Skor Pengetahuan Kader pada Pengukuran Pre-Post Test tentang Deteksi Dini Stunting Menggunakan Media Aplikasi PPAK ( $\mathrm{n}=35$ kader)

\begin{tabular}{lcccc}
\hline $\begin{array}{c}\text { Variabel } \\
\text { Pengetahuan }\end{array}$ & Median & Min - Max & Standar Deviasi & N \\
\hline Pre-test & 12 & $5-16$ & 2.395 & 35 \\
Post-test & 15 & $11-18$ & 2.313 & 35 \\
\hline
\end{tabular}

\section{Analisis Bivariat}

Analisis bivariat digunakan untuk mengetahui pengaruh variabel independen dengan variabel dependen yang ditunjukkan dengan nilai $p<0,05$. Berdasarkan uji Willcoxon terdapat perubahan nilai sebelum dan sesudah diberikan intervensi. Positive Ranks dengan nilai 33 artinya 33 sampel mengalami peningkatan nilai dari pre-test ke post-test, Negative ranks adalah 0 berarti tidak ada nilai post-test yang lebih rendah dibandingkan nilai pre-test, serta nilai Ties adalah 2 berarti terdapat 2 sampel yang memiliki nilai pre-test dan post-test sama. Nilai p-value yang didapatkan berdasarkan uji wilcoxon adalah 0,000 ( $p$-value $<0,05$ ). Hal ini menunjukkan adanya pengaruh media aplikasi PPA Kader terhadap pengetahuan Kader Posyandu dalam deteksi dini stunting.

Tabel 2. Perbedaan Pengetahuan Kader tentang Deteksi Dini Stunting pada PrePost Test Menggunakan Media Aplikasi PPAK

\begin{tabular}{cccccc}
\hline $\begin{array}{c}\text { Variabel } \\
\text { Pengetahuan }\end{array}$ & N & $\begin{array}{c}\text { Positive } \\
\text { Ranks }\end{array}$ & $\begin{array}{c}\text { Negative } \\
\text { Ranks }\end{array}$ & Ties & $\boldsymbol{p}$ \\
\hline $\begin{array}{c}\text { Pre-test } \\
\text { Post-test }\end{array}$ & 35 & 33 & 0 & 2 & 0.000 \\
*Willcoxon test & & & & &
\end{tabular}

\section{PEMBAHASAN}

Hasil penelitian telah dilaporkan terdapat peningkatan pengetahuan kader Posyandu tentang deteksi dini stunting setelah diberikan intervensi menggunakan media aplikasi PPA Kader. Menurut peneliti, media pendidikan kesehatan berupa aplikasi smarphone PPA Kader ini dapat mempengaruhi tingkat pengetahuan kader Posyandu. Hal ini disebabkan karena adanya informasi yang mendukung mengenai stunting yang ada dalam aplikasi PPA Kader. Hal ini didukung oleh teori yang menyebutkan bahwa semakin sering seseorang menerima informasi maka pengetahuan serta wawasannya akan semakin meningkat, sedangkan jika tidak mendapatkan informasi maka pengetahuan dan wawasannya tidak akan meningkat (Margawati and Astuti, 2018).

Hal ini sejalan dengan penelitian yang dilakukan oleh Wahyuni, T tahun 2017 yang menunjukkan adanya peningkatan pengetahuan dan keterampilan dalam merangsang tumbuh kembang balita melalui penggunaan aplikasi smartphone mother care(Tri Wahyuni, 2017). Hal ini juga didukung oleh penelitian yang menunjukkan bahwa penggunaan aplikasi Anak Bebas Stunting (ABS) telah meningkatkan pengetahuan kader tentang stunting. Terdapat peningkatan pengetahuan kader sebesar 25.1\%(Handayani, Tarawan and Nurihsan, 2019). Selain itu, penelitian yang dilakukan oleh Yossy dan Yanti tahun 2020, rata-rata skor pengetahuan sebelum diberikan intervensi dengan media aplikasi offline tentang stunting adalah 5.96, sedangkan rata-rata skor pengetahuan setelah diberikan intervensi dengan media aplikasi offline tentang stunting meningkat menjadi 8.65 (Utario and Sutriyanti, 2020).

Lebih lanjut, juga telah dilaporkan bahwa terdapat pengaruh media aplikasi PPA Kader terhadap pengetahuan kader Posyandu dalam deteksi dini stunting. Menurut peneliti, perkembangan teknologi informasi saat ini sangat berkembang pesat. Hal ini merupakan sarana yang dapat digunakan untuk bertukar informasi dalam mendapatkan pengetahuan. 
Salah satu perkembangan teknologi yang dapat digunakan dalam meningkatkan pendidikan kesehatan yaitu penggunaan smartphone. Aplikasi dalam smartphone dapat membantu seseorang untuk mempermudah dalam mendapatkan informasi. Smartphone memiliki tambahan aplikasi, internet akses, pesan singkat, penerima email, dan lain-lain. Hal ini didukung oleh penelitian Nillatuizzah, Bakhar, dan Istiqomah tahun 2018 yang menunjukkan adanya peningkatan pengetahuan setelah diberikan intervensi media aplikasi dalam smartphone dengan nilai $p$ sebesar 0,035 $(<0,05)$ (Izah, Bakhar and Andari, 2018).

Aplikasi PPA Kader tidak hanya digunakan untuk deteksi dini stunting saja karena aplikasi ini merupakan aplikasi yang dapat digunakan untuk pemantauan pertumbuhan balita usia $0-60$ bulan berdasarkan nilai Z-Score. Aplikasi ini juga dapat digunakan untuk mendeteksi adanya wasting pada balita. Selain itu, aplikasi ini juga memuat informasi mengenai deteksi dini stunting dalam bentuk video animasi atau audiovisual. Berdasarkan hal kelebihan dan fitur yang ada dalam aplikasi PPA Kader, menurut peneliti masyarakat akan lebih mudah untuk memahami dan menerapkan dalam setiap kegiatan pengukuran tinggi badan balita dan penimbangan berat badan balita pada saat Posyandu sehingga dapat mempermudah untuk melakukan deteksi dini stunting.

Media audiovisual adalah alat bantu pendidikan yang dapat menstimulus indera penglihatan dan pendengaran yang terdiri dari suara dan gambar. Media audiovisual ini dapat meningkatkan persepsi, meningkatkan pengetahuan, dan meningkatkan ingatan seseorang (Apriliawati et al., 2020). Hal ini sejalan dengan penelitian Noerma dan Ratih tahun 2020 yang menunjukkan peningkatan pengetahuan kader mengenai bahaya tersedak pada bayi dengan menggunakan media audiovisual (Rizqiea and Utami, 2020).

Selain itu, hasil penelitian ini juga sejalan dengan penelitian yang dilakukan oleh Juniah, Anita, dan Suhendar (2020), bahwa terdapat perbedaan rata-rata pengetahuan orang tua sebelum dan sesudah pemberian edukasi menggunakan media audiovisual(Apriliawati et al., 2020). Hasil penelitian yang dilakukan oleh Anisha, Farit, dan Akifah (2017), penyuluhan dengan media audiovisual secara signifikan efektif untuk meningkatkan pengetahuan kesehatan mengenai pencegahan penyakit gastritis dibandingkan media leaflet (Permatasari, rezal and Munandar, 2017). Hal ini dapat disimpulkan bahwa pemberian edukasi menggunakan aplikasi PPA Kader ini terbukti ada pengaruh dalam meningkatkan pengetahuan kader Posyandu tentang deteksi dini stunting.

Namun, Penelitian ini memiliki keterbatasan yaitu penelitian ini menggunakan metode penelitian pre-experimental dalam one group pre-test and post-test design sehingga peneliti tidak dapat membandingkan hasil pendidikan kesehatan dengan kelompok yang tidak diberikan intervensi/kelompok kontrol.

\section{KESIMPULAN DAN SARAN}

Berdasarkan pada hasil penelitian di atas maka dapat disimpulkan bahwa terdapat pengaruh media aplikasi PPA Kader terhadap pengetahuan kader Posyandu tentang Deteksi Dini Stunting yaitu adanya peningkatan pengetahuan kader tentang deteksi dini stunting. Aplikasi PPA Kader ini hendaknya dapat digunakan secara berkelanjutan sebagai media pembelajaran yang menarik dan informatif. Selain itu, diharapkan peneliti selanjutnya dapat menambahkan jumlah responden dan variabel yang digunakan.

\section{DAFTAR PUSTAKA}

Adistie, F., Lumbantobing, V. B. M. and Maryam, N. N. A. (2018) 'Pemberdayaan Kader Kesehatan Dalam Deteksi Dini Stunting dan Stimulasi Tumbuh Kembang pada Balita', Media Karya Kesehatan, 1(2), pp. 173-184. doi: 10.24198/mkk.v1i2.18863.

Al, A. et (2015) 'Faktor-faktor yang Mempengaruhi Kejadian Stunting pada Anak Balita di Wilayah Pedesaan dan Perkotaan (The Factors Affecting Stunting on Toddlers in Rural and Urban Areas)', Jurnal Pustaka Kesehatan, 3(1), pp. 163-167. doi: 10.1007/s11746-013$2339-4$.

Apriliawati, A. et al. (2020) 'Media Booklet Dan Udiovisual Efektif Terhadap Pengetahuan Orangtua dengan Balita Stunting', Jurnal Ilmiah Kesehatan, 9(2), pp. 60-65. Available at: https://ejournal.umpri.ac.id/index.php/JI K/article/download/1217/656.

Arthatiani, F. Y., \& Zulham, A. (2019) 'Konsumsi Ikan Dan Upaya 
Penanggulangan Stunting Di Provinsi Daerah Khusus Ibukota Jakarta', Buletin Ilmiah Marina Sosial Ekonomi Kelautan dan Perikanan, 5(2), pp. 95-104. doi: http $/ /$ dx.doi.org/10.15578/marina.v5i2.8 107.

Azizah, E. N. and Wardhani, R. K. (2020) 'Gerakan Kader Posyandu Sadar Stunting di Desa Ringinpitu Kecamatan Plemahan', Journal of Community Engagement in Health, 3(2), pp. 229 232. doi: 10.30994/jceh.v3i2.70.

Handayani, T. P., Tarawan, V. M. and Nurihsan, J. (2019) 'Peningkatan Pengetahuan Dan Sikap Kader Tentang Stunting Pada Balita Usia 12 - 36 Bulan Melalui Penerapan Aplikasi Anak Bebas Stunting (Abs)', Jurnal Kebidanan Malahayati, 5(4), pp. 357-363. doi: $10.33024 / \mathrm{jkm} . \mathrm{v} 5 \mathrm{i} 4.2058$.

Izah, N., Bakhar, M. and Andari, I. D. (2018) 'Pengaruh Penggunaan Aplikasi Stimulasi Tumbuh Kembang Terhadap Pengetahuan Ibu Dan Pertumbuhan Balita Umur 9 - 24 Bulan', Siklus : Journal Research Midwifery Politeknik Tegal, 7(2), p. $328 . \quad$ doi: 10.30591/siklus.v7i2.897.

Kementerian Kesehatan RI (2018) 'Hasil Utama Riset Kesehata Dasar (RISKESDAS) 2018', Journal of Physics A: Mathematical and Theoretical, 44(8), pp. 1-200. doi: 10.1088/17518113/44/8/085201.

Maharani, S. D. S., Wulandari, S. R. and Melina, F. (2018) 'Hubungan Antara Kejadian Stunting Dengan Perkembangan Pada Balita Usia 3-5 Tahun Di Posyandu Kricak Yogyakarta', Jurnal Ilmiah Kesehatan, 7(1), pp. 3746. doi: 10.35952/jk.v7i1.118.

Margawati, A. and Astuti, A. M. (2018) 'Pengetahuan ibu, pola makan dan status gizi pada anak stunting usia 1-5 tahun di Kelurahan Bangetayu, Kecamatan Genuk, Semarang', Jurnal Gizi Indonesia (The Indonesian Journal of Nutrition), 6(2), pp. 82-89. doi: 10.14710/jgi.6.2.8289.

Permatasari, A., rezal, F. and Munandar, S. (2017) 'Efektifitas Media Audio Visual Dan Leaflet Terhadap Peningkatan Pengetahuan, Sikap Dan Tindakan Tentang Pencegahan Penyakit Gastritis
Pada Santriwati Di Pondok Pesantren Hidayatullah Putri Dan Ummusshabri Kota Kendari Tahun 2017', Jurnal Ilmiah Mahasiswa Kesehatan Masyarakat Unsyiah, 2(6), p. 184073. doi: 10.37887/jimkesmas.

Purnamasari, H. et al. (2020) 'Pelatihan Kader Posyandu Sebagai Upaya Pencegahan Stunting Pada Balita Di Wilayah Kerja Puskesmas Margadana Dan Puskesmas Tegal Selatan Kota Tegal', Jurnal Kesehatan Masyarakat (e-Journal), 8(3), pp. 432-439.

Pusat Data dan Informasi Kemenkes RI (2018) 'Buletin Jendela Data dan Informasi Kesehatan', Kementerian Kesehatan RI, p. 56. doi: 10.1017/ CBO9781107415324.004.

Rahayu, R. (2017) 'Peran Kader Posyandu Dalam UpayaPeningkatan Pemanfaatan Posyandu Di Wilayah Kerja Puskesmas Mokoau Tahun 2017', Jurnal Ilmiah Kesehatan Masyarakat, 2(6), pp. 1-7. Available at: http://ojs.uho.ac.id/ index.php/JIMKESMAS/article/viewFile /3427/2582.

Rizqiea, N. S. and Utami, R. D. P. (2020) 'Edukasi Dengan Metode Audiovisual Sebagai Upaya Peningkatan Pengetahuan Kader Mengenai Bahaya Tersedak Pada Bayi', Jurnalempathy.Com, 1(2), pp. 96101. doi: 10.37341/jurnalempathy. v1i2.24.

Sulistianingsih, A. and Yanti, D. A. M. (2016) 'Kurangnya Asupan Makan Sebagai Penyebab Kejadian Balita Pendek (Stunting)', Jurnal Dunia Kesehatan, 5(1), pp. 71-75. Available at: https://www.neliti.com/publications/7712

3/kurangnya-asupan- makan-sebagaipenyebab- kejadian-balita-pendekstunting.

Tri Wahyuni (2017) 'Pengaruh Aplikasi Mother Cares (MOCA) terhadap Peningkatan Pengetahuan dan Keterampilan Orang Tua dalam Melakukan Stimulasi Tumbuh Kembang Balita Usia 12-18 Bulan', Jurnal Medika Cendikia, 04(1), pp. 2836. Available at: https://jurnalskhg.ac.id/ index.php/medika/article/view/61/60.

Utario, Y. and Sutriyanti, Y. (2020) 'Aplikasi Offline Stunting Untuk Meningkatkan Pengetahuan Kader Posyandu di Puskesmas Perumnas Kabupaten Rejang 
Lebong', Jurnal Abdimas Kesehatan Perintis, 2(1), pp. 25-30. Available at: https://www.jurnal.stikesperintis.ac.id/in dex.php/JAKP/article/view/438.

Yadika, A. D. N., Berawi, K. N. and Nasution, S. H. (2019) 'Pengaruh Stunting terhadap
Perkembangan Kognitif dan Prestasi Belajar', Jurnal Majority, 8(2), pp. 273282. Available at: http://juke.kedokteran. unila.ac.id/index.php/majority/article/vie $\mathrm{w} / 2483$. 